\title{
EDITORIAL
}

\section{The edge of academia: in search of new paths}

\author{
PhD. HÉLIO ARThUR ReIS IRIgaraY ${ }^{1}$ \\ ${ }^{1}$ Fundação Getulio Vargas / Brazilian School of Public and Business Administration, Rio de Janeiro - RJ, Brazil
}

\begin{abstract}
Renato Terra is one of the directors of the documentary 'Uma Noite em 67' (A night in 1967), which portrays the Festival of Brazilian Popular Music promoted by TV Record in that year. In a recent article published in the newspaper Folha de S. Paulo, Terra (2020) told that in one of the preliminary versions of the film, there was an excerpt showing the moment in which Sérgio Ricardo broke his guitar. In the excerpt, the incident was interspersed with testimonials emphasizing the severity of that act. The executive producer João Moreira Salles convinced the directors (Terra and Ricardo Calil) to cut that part, arguing that the singer's long presentation without interruptions would lead viewers to experience the anguish of the artist, who was booed, interrupted, and harassed until, in a sudden outburst, he broke his guitar and left the stage.
\end{abstract}

In the recent documentary 'Democracia em Vertigem' (The Edge of Democracy), director Petra Costa provokes a debate about Brazilian democracy when analyzing the last years of Brazilian politics, especially the impeachment of President Dilma Rousseff. The director puts herself openly by narrating the plot. At no time does she omit her leftist positioning and understanding that the impeachment was a "coup." Does that make the documentary a work of fiction?

According to Terra (2020), "a good documentary is not the one that seeks, in a didactic way, to teach something. Wikipedia does that."

What can academia learn from Terra's testimony and from the criticism of Costa's work?

Initially, all research is produced in a social environment, formed by four dimensions. The dimension of social demand encompasses how - and why - we, researchers, are co-opted by our themes, which include the story of our lives, vanity, and even financial return. This dimension demands the contextualization not only of the society of discourse (Bourdieu) but also of how this society exercises control over the research.

The axiological dimension cannot be overlooked. It is composed of the social, individual, cultural, and technical values that condition research. There is no denying the fact that the cultural values of society impose the choice of problems - a fact that Weber (1946) understands as a "relation of values."

The third is the doxological dimension, a dimension of the non-systematized knowledge, of the language, and the evidence of everyday practice. In this dimension, scientific practice must work to pull out specific problems, the famous "somnambulistic certainty" (MANNHEIM, 1928). The nosography (WITTGENSTEIN, 1993) is proposed in this dimension as a form of purging the scientific language of contamination by vague and imprecise prenotions.

Finally, there is the epistemic dimension, which contemplates cutting edge theories as well as the most advanced epistemological reflection, research strategies, and multidisciplinary approaches.

As I take the position of Editor-in-chief of the journal Cadernos EBAPE.BR, I use this opportunity to reiterate that we welcome works from all ontological perspectives, be they theoretical or empirical. We look for surprising articles that present and discuss facts that are not easily predicted by theories. Therefore, the authors must guarantee the methodological rigor, as well as discuss the importance and implications of these discoveries for managerial and organizational research.

May we be able, in academia, to be bold like Renato Terra, Ricardo Calil, and Petra Costa. The important thing is to be faithful to our truth and together, even though walking different paths, build and strengthen our field of knowledge.

It is with great pride that I present to you the first issue of Cadernos EBAPE.BR of 2020. In this issue, Marcia Prezotti Palassi, Raiane Gonçalves de Oliveira Martinelli, and Ana Paula Paes de Paula discuss the dynamics of political awareness in the Junior Enterprise Movement in the article "Between entrepreneurial discourse and political awareness: an exploratory study of the Junior Enterprise Movement at a public university in Southeast Brazil." 
In the article "Between emergency, submersion, and silence: LGBT as a research category in Administration," Maurício Donavan Rodrigues Paniza reflects on the representativeness of the groups that are part of the acronym LGBT in research in administration.

Fernando Filardi, Rachel Mercedes P. de Castro, and Marco Tulio Fundão Zanini analyze the experiences of the Brazilian Federal Data Processing Service (SERPRO) and the Federal Revenue Service, revealing the advantages and disadvantages of teleworking in public administration in their article "Advantages and disadvantages of teleworking in Brazilian public administration: analysis of SERPRO and Federal Revenue experiences."

In the essay "The Deleuze-Guattarian Rizoma in Organizational Studies Research," the authors Raquel de Oliveira Barreto, Alexandre de Pádua Carrieri, and Roberta Carvalho Romagnoli discuss the use of the concept of Rhizome, developed by Deleuze and Guattari, within the scope of the research in Organizational Studies.

The article "Public policy to support the development of LPA's: an impact analysis in Minas Gerais, Brazil," analyzes the public policy contributing to LPAs in Minas Gerais, considering its impacts on development. The authors are Cecilia Alves da Silva Antero, Cristiana Tristão Rodrigues, Magnus Luiz Emmendoerfer, and Valdir Roque Dallabrida.

The systematization of the knowledge produced about inter-organizational learning in networks of micro and small companies is the central theme of the article "Interorganizational learning in networks of micro and small enterprises: an integrative look at the literature," written by Abimael Magno do Ouro Filho, Maria Elena Leon Olave, and Ikaro Daniel de Carvalho Barreto.

In "Development of a model for the analysis of public policy networks in a federalism and coalitional presidentialism context," Luciana Nunes Goulart and Diego Mota Vieira propose a useful model for the analysis of Brazilian public policy networks. The model innovates by incorporating into the network analysis the aspects of coalition federalism and presidentialism, considering them crucial aspects of power relations in Brazil.

In the article "The rationality of decisions in the university professors' inter-professional transitions," written by Elza Fátima Rosa Veloso, Joel Souza Dutra, Rodrigo Cunha da Silva, and Leonardo Nelmi Trevisan, the authors analyze the rationality of decisions made by university professors in their transition from other professions to the teaching career.

Rodrigo Seefeld and Natália Rese analyze how the media translates the role of players involved in Operation Car Wash, the events, the relationships, antecedents, and consequences, producing narrative versions consumed by society, in " $\mathrm{A}$ word is enough to the wise?!": a study on narratives produced by the media when translating the role of the players involved in the Operation Car Wash in Brazil."

To identify, present, and analyze symbolic forms related to the operation of capitalist axiomatic in the home, Ana Carolina dos Santos Bortolini, Carmem Ligia lochins Grisci, and Ana Elísia da Costa produced the exploratory study "Living-working and the axiomatic of capitalism: a study based on media outlets in the architecture, decoration, and design segments."

"Vulnerable careers: analysis of media layoffs as a turning point for journalists" by Liana Haygert Pithan, Marcia Cristiane Vaclavik, and Andrea Poleto Oltramari, addresses how the dismissal affects a subject's perspective and forces a worker to reflect on future projections of the profession and career.

From the perspective of Michel de Certeau on the study of everyday life, Luana Furtado Vilas Boas and Elisa Yoshie Ichikawa studied the daily practices of territorialization of workers from the Brazilian state of Alagoas, sugar cane cutters, who, in the midst of precarious work, migrate to work in plantations in the state of Paraná in "Migrant sugarcane cutters in Paraná: daily practices and processes of territorialization in the context of precarious work."

"Corporate political strategies: the case of the Brazilian railway sector" by Rodrigo Oliveira da Silva, Teresia Diana Lewe van Aduard de Macedo-Soares, and Sérgio Augusto Pereira Bastos, aimed to identify the corporate political strategies employed by railway concessionaires of Brazilian cargo.

Also in this issue, Evangelina da Silva Sousa, Luis Eduardo Brandão Paiva, Alexandre Rodrigues Santos, Sílvia Maria Dias Pedro Rebouças, and Raimundo Eduardo Silveira Fontenele invite the readers to reflect on "The influence of religious beliefs on entrepreneurial intention: an analysis from the perspective of the Theory of Planned Behavior."

Finally, we present the review of the book "Influência do pós-doutorado sobre produção científica da pós-graduação: o caso da USP" (The influence of the post-doctorate on the scientific production in graduate programs: The case of the University of São Paulo - USP) written by Luis Faria Aboim Tavares.

I wish you a pleasant read!

PHD. HÉLIO ARTHUR REIS IRIGARAY

EDITOR-IN-CHIEF 


\section{REFERENCES}

MANNHEIM, K. Beiträge zur Theorie der Weltanschauungsinterpretation. 1928. Arquivo capturado eletronicamente. Accessed on: Feb. 05, 2020

TERRA, R. Imparcialidade em documentários é ideia superada há muito tempo. Folha de São Paulo, São Paulo, 03 February 2020. Available at: <https://www1.folha.uol.com.br/ilustrada/2020/02/ imparcialidade-em-documentarios-e-ideia-superada-ha-muito-tempo. shtml>. Accessed on: Feb. 05, 2020.

WEBER, M. Ensaios de Sociologia. Rio de Janeiro: Editora Zahar, 1946. WITTGENSTEIN, L. Tractatus Logico-Philosophicus. São Paulo: Editora Universidade de São Paulo, 1993.

PhD. Hélio Arthur Reis Irigaray

ORCID: https://orcid.org/0000-0001-9580-7859

PhD from FGV EAESP, master in business administration from PUC-Rio, and a bachelor degree in economics from the University of Northern lowa, USA. Adjunct professor at FGV EBAPE and the Corporate International Master Program (CIM), Georgetown University, Washington, USA; Leader of the theme 'diversity and labor relations' in the line of research 'work management' (ANPAD). E-mail: helio.irigaray@fgv.br 